\title{
An Economic Analysis of Production and Marketing of Mizo Bird's Eye Chilli (Mizo Chilli) in Aizawl District of Mizoram State
}

\author{
Lalhminghlui, G. Sunil Kumar Babu, R. Asha*, S. Shrine and S. K. Gousiya \\ Department of Agricultural Economics, Agricultural College, Acharya N. G Ranga \\ Agricultural University, Bapatla, India \\ *Corresponding author
}

\section{A B S T R A C T}

\section{Keywords}

Mizochilli, Bird's eye chilli,

Production, Price spread, Marketing efficiency

Article Info

Accepted: 12 September 2020 Available Online: 10 October 2020
The present study is based on information collected from 60 mizochilli growers and 20 marketing functionaries in Aizawl district of Mizoram in the crop year 2017-18, through pre-tested well design schedule. The results indicated the average productivity of mizo chili on sample holding was 10.72 quintal per hectare and the cost cultivation on per hectare basis was Rs. 97618.56. The gross income per hectare of this crop was found to be around Rs. 157613. The Benefit Cost ratio of 1.61 was observed. Production function analysis shows that human labour, machine labour and seed had significantly influenced output at $1 \%$ level of significance. The farmer obtained $96.34 \%$ and $41.2 \%$ of price paid by consumer in marketing Channel I (Farmer $\rightarrow$ Retailer) and Channel II (Farmer $\rightarrow$ Village trader $\rightarrow$ Retailer) respectively. The marketing cost incurred by producers was $4.10 \%$ of consumer's rupee in channel I and $0.45 \%$ of consumer's rupee in Channel II.

\section{Introduction}

Mizo bird's eye chilli (mizochilli) is one of the major spices cultivated in Mizoram state. It was named so due to the bird's eye-like appearance when it is looked from end of the stem. Mizo bird's eye chillies (mizochillies) are smaller in size and hotter than the normal Indian red chillies. In terms of pungency, it measures around 50,000 - 100,000 Scoville units. "Mizochilli" got recognition of geographical indication (GI) tag in March 2015. The area under chilli cultivation in Mizoram is around 11000 ha (2016-17) and its production is 10727.35 MT (2016-17). A large portion of Chili production is exported to neighboring states like Assam. Jhoomfarming (slash and burn method) is mainly practiced for cultivation of chilli in Mizoram. Bird's eye chilli can also be found in Meghalaya, Assam, and Kerala. It is used in traditional dishes of the Kerala cuisine in India.

The objectives of the study are to estimate the cost and returns, analyse recourse use efficiency, estimating marketing cost, price spread and marketing efficiency of mizochilli. 


\section{Materials and Methods}

Aizawl district was purposively selected as it consists high number of chilli growers. The three highest chilli growing villages within Aizawl district were selected, namely, Tachhip, Sialsuk and East Phaileng and 20 chilli growers from each village were selected randomly to make a sample size of 60 . A sample of 20 market functionaries involved in the marketing process was randomly selected for the present study.

Data was collected pertaining to the agricultural year 2017-18 by interviewing the individual farmers and market functionaries with structured schedule. The information regarding area, production and prices of chilli were collected from Directorate of Horticulture, Aizawl.

\section{Analysis of data}

\section{Cost and returns}

Tabular analysis method based on means and percentages was used for estimating costs and returns.

The input costs were calculated using six cost concepts approved by Commission for Agricultural Costs and Prices (CACP) which are Cost $A$, Cost $B_{1}$, Cost $B_{2}$, Cost $C_{1}$, Cost $\mathrm{C}_{2}$ and $\operatorname{Cost} \mathrm{C}_{3}$.

\section{$\operatorname{Cost} \mathbf{A}_{1}$}

This includes value of hired human labour +charges on owned and hired machinery + value of seed (both farm produced and purchased + value of owned and purchased manures + value of fertilizers + value of plant protection chemicals used + depreciation, repairs and maintenance of farm machinery and farm implements and farm buildings + land revenue and interest on working capital.

\section{Cost $\mathbf{B}_{1}$}

This covers Cost A + interest on value of fixed capital assets (excluding land).

\section{Cost $\mathbf{B}_{2}$}

This covers Cost $\mathrm{B}_{1}+$ rental value of owned land.

\section{Cost $\mathbf{C}_{1}$}

This covers Cost $\mathrm{B}_{1}+$ imputed value of family labour.

\section{Cost $\mathrm{C}_{2}$}

This covers Cost $\mathrm{B}_{2}+$ imputed value of family labour.

\section{Cost $\mathrm{C}_{3}$}

This covers Cost $\mathrm{C}_{2}+$ value of management input at 10 per cent of total cost.

\section{Resource use efficiency}

The production function model, as stated by Cobb-Douglas (1928), which employs log linear regression to evaluate the productivity of the major inputs was used to analyse the efficiency of the inputs used in the production of mizochilli. The production function model was expressed implicitly as

$\mathrm{Y}=\mathrm{aX}_{1}{ }^{\mathrm{b} 1} \mathrm{X}_{2}^{\mathrm{b} 2} \mathrm{X}_{3}{ }^{\mathrm{b} 3} \mathrm{X}_{4}{ }^{\mathrm{b} 4} \mathrm{X}_{5}^{\mathrm{b} 5}$

Where,

$\mathrm{Y}=$ Yield $(\mathrm{kg} / \mathrm{ha})$

$\mathrm{A}=$ Constant or intercept value

b1, b2 ...b5 = Regression coefficients

$\mathrm{X}_{1}=$ human labour (days/ha)

$\mathrm{X}_{2}=$ machine labour (hours/ha)

$\mathrm{X}_{3}=$ quantity of seeds $(\mathrm{kg} / \mathrm{ha})$

$\mathrm{X}_{4}=$ quantity of fertilizers $(\mathrm{kg} / \mathrm{ha})$ 
$\mathrm{X}_{5}=$ quantity of plant protection used $(\mathrm{kg} / \mathrm{ha}$ or $\mathrm{L} / \mathrm{ha}$ )

The logarithmic from of the Cobb-Douglas function is expressed as under:

$\log \mathrm{y}=\log \mathrm{a}+\mathrm{b} 1 \log \mathrm{x}_{1}+\mathrm{b} 2 \log \mathrm{x}_{2}+\mathrm{b} 2 \log$ $\mathrm{x}_{3}+\mathrm{b} 4 \log \mathrm{x}_{4}+\mathrm{b} 5 \log \mathrm{x}_{5}$

\section{Marketing Efficiency (ME)}

The marketing efficiency was worked out by method suggested by Acharya and Agarwal (2001) and calculated as follows

$M E=\frac{N P}{M C+M M}$

$\mathrm{ME}=$ Marketing efficiency

$\mathrm{NP}=$ Net price of the producers

$\mathrm{MC}=$ Total marketing cost

$\mathrm{MM}=$ Marketing margin

\section{Results and Discussion}

\section{Economics of chili production:}

\section{Per hectare cost of cultivation}

The data in Table 1 reveals that the average estimate of cost of mizochilli cultivation on per hectare basis was Rs. 97618.56. The study revealed that majority of the working capital was spent on hired labours i.e., Rs. 27910 and least amount was spent on fertilizer i.e., Rs. 76.65. The farmers practiced Jhum farming (slash and burn method). In most cases when the fields were not burnt properly due to rainfall, large amount of labours were required for clearing of the field after firing which was attributed to the heavy capital utilization on labours.

\section{Per hectare profitability}

Yield in quintals, gross income, net income and B.C. ratio were the tools employed for estimating the economics of production of crop. For this purpose, the profitability of chilli per hectare at different profitability measures is presented in Table 2. The average productivity of mizochilli on sample holding was found to be 10.72 quintal per hectare. The price per quintal received by the different farmers was found to vary according to disposal pattern, time of selling and locality of the farmers. The average price received per quintal was found to be Rs. 14700. The average gross income per hectare of this crop was found to be around Rs. 157613. The other measurement of farm profit like net farm income on average was found to be around Rs. 59995 per hectare. The average B.C. ratio of 1.61 was observed.

\section{Production function analysis}

The effect of inputs on the production of mizochilli was determined by a CobbDouglas production function analysis. From Table 3, the value of $\mathrm{R}^{2}$ shows that $74.52 \%$ of variation in mizo chili output in the study area can be explained by the independent variables. The unexplained variation might be due to the inter farm difference in soil fertility and other exogenous factors. Human labour, machine had shown significant effect on yield of chilli at 1 per cent level of significance whereas labour and seeds were found significant at 5 per cent level of significance. This indicates that every one per cent increase in human labour, machine labour and seed, keeping other factors constant, there would be an increase in gross returns by 0.47 per cent, 0.02 percent and 0.09 per cent respectively as depicted in Table 1. The fertilizers and plant protection chemicals were found to have no significant impact on output. Most of the farmers did not use any chemicals which was commonly found in jhum method of farming therefore the average amount utilized were very less that it could not have a significant impact on yield. 
Table.1 Cost of Cultivation of mizochilli on sample holding

\begin{tabular}{|l|l|l|}
\hline S.No & Cost particulars & Rs/ha \\
\hline $\mathbf{1}$ & Hired Human labour & 27910 \\
\hline $\mathbf{2}$ & Machine labour & 2250 \\
\hline $\mathbf{3}$ & Seed & 1262.6 \\
\hline $\mathbf{4}$ & Fertilizer & 76.65 \\
\hline $\mathbf{5}$ & Plant protection & 105.6 \\
\hline $\mathbf{6}$ & Plant Growth Promoter & 390 \\
\hline $\mathbf{7}$ & Composting agent & 390 \\
\hline $\mathbf{8}$ & Interest on working capital & 4048.1 \\
\hline $\mathbf{9}$ & Land revenue & 80 \\
\hline & Cost A & 36532.95 \\
\hline $\mathbf{1 0}$ & Interest on fixed capital & 1500 \\
\hline & Cost B1 & 38032.95 \\
\hline $\mathbf{1 1}$ & Rental value of land & 12500 \\
\hline & Cost B2 & 50532.95 \\
\hline $\mathbf{1 2}$ & Imputed value of family labour & 38211.2 \\
\hline & Cost C1 & 74744.15 \\
\hline & Cost C2 & 88744.15 \\
\hline & Cost C3 (C2 + 10\% of C2) & 97618.56 \\
\hline
\end{tabular}

Table.2 Profitability of mizochilli crop

\begin{tabular}{|l|l|l|}
\hline Sl. No. & Returns & Quantum \\
\hline $\mathbf{1}$ & Output (q/ha) & 10.72 \\
\hline $\mathbf{2}$ & Gross Income (Rs/ha) & 157613.4 \\
\hline $\mathbf{3}$ & Net Income (Rs/ha) & 59994.84 \\
\hline $\mathbf{4}$ & B:C ratio & 1.61 \\
\hline
\end{tabular}

Table.3 Regression results for mizochilli production

\begin{tabular}{|l|l|l|}
\hline S.No & Production variables & Regression value \\
\hline $\mathbf{1}$ & Human labour & $0.474 * * \quad(0.109)$ \\
\hline $\mathbf{2}$ & Machine labour & $0.023^{*}(0.0140$ \\
\hline $\mathbf{3}$ & Seeds & $0.092 *(0.088)$ \\
\hline $\mathbf{4}$ & Fertilizer & 0.005 N.S $(0.015)$ \\
\hline $\mathbf{5}$ & Plant protection & 0.020 N.S $(0.021)$ \\
\hline & $\begin{array}{l}\text { }^{2} \text { Coefficient of multiple determination } \\
(\%)\end{array}$ & $74.52 \%$ \\
\hline & F ratio & $7.608^{*}$ \\
\hline
\end{tabular}

Note: Figures in parentheses indicate standard errors of respective co-efficient.

* indicates 5 per cent level of significance

** indicates 1 per cent level of significance 
Table.4 Marketing cost, margin and price spread of mizochilli in channel- I

\begin{tabular}{|l|l|c|c|}
\hline S.No & Particulars & $\begin{array}{c}\text { Amount } \\
(\mathbf{R s} / \mathbf{q})\end{array}$ & $\begin{array}{c}\text { Producer's share in } \\
\text { consumer's rupee } \\
(\mathbf{\%})\end{array}$ \\
\hline $\mathbf{1}$ & Producer's net price & 16377.8 & 96.34 \\
\hline $\mathbf{2}$ & \begin{tabular}{l} 
Cost incurred by producer \\
\hline
\end{tabular} & & \\
\hline & Transportation & 622.2 & 3.66 \\
\hline & $\begin{array}{l}\text { Loading and unloading } \\
\text { Plastic bags }\end{array}$ & 25 & 0.14 \\
\hline & $\begin{array}{l}\text { Total marketing cost of producer } \\
\text { Producer's sale price/Consumer's paid } \\
\text { price }\end{array}$ & 697.2 & 0.29 \\
\hline
\end{tabular}

Table.5 Marketing cost, margin and price spread of mizochilli in channel-II

\begin{tabular}{|c|c|c|c|}
\hline S. No & Particulars & Amount (Rs/q) & $\begin{array}{l}\text { Producer's share in } \\
\text { consumer's rupee }(\%)\end{array}$ \\
\hline 1 & Producer's net price & 9890 & 41.20 \\
\hline \multirow[t]{5}{*}{2} & Cost incurred by producer & & \\
\hline & Transportation & 100 & 0.41 \\
\hline & Loading and unloading & 10 & 0.04 \\
\hline & Total marketing cost of producer (A) & 110 & 0.45 \\
\hline & $\begin{array}{l}\text { Producer's sale price/village trader's } \\
\text { purchase price }\end{array}$ & 10000 & 41.66 \\
\hline \multirow[t]{8}{*}{3} & Cost incurred by village trader & & \\
\hline & Transportation & 283 & 1.17 \\
\hline & Loading and unloading & 100 & 0.41 \\
\hline & Plastic bags & 55 & 0.22 \\
\hline & $\begin{array}{l}\text { Total marketing cost of village trader } \\
\text { (B) }\end{array}$ & 438 & 1.82 \\
\hline & Net margin of village trader & 13562 & 56.50 \\
\hline & Total marketing cost $(\mathrm{A}+\mathrm{B})$ & 548 & 2.28 \\
\hline & $\begin{array}{l}\text { Village trader's saler price/ Consumer's } \\
\text { paid price }\end{array}$ & 24000 & 100 \\
\hline
\end{tabular}

Table.6 Marketing efficiency index of mizochilli in marketing channel I and II

\begin{tabular}{|l|c|c|}
\hline \multirow{2}{*}{ Particulars } & \multicolumn{2}{|c|}{ Marketing Channels } \\
\cline { 2 - 3 } & Channel I & Channel II \\
\hline Net price received by producer & 16377.8 & 9890 \\
\hline Marketing cost & 697.2 & 548 \\
\hline Marketing margin & 0 & 13562 \\
\hline $\begin{array}{l}\text { Marketing efficiency (using } \\
\text { Acharya-Agarwal method) }\end{array}$ & 23.49 & 0.70 \\
\hline
\end{tabular}


Although the $\mathrm{F}$ ratio is only 7.608 , it is statistically significant at $5 \%$ level of significance which indicates that the model provides a better fit to the data than a model that contains no independent variables (i.e. intercept only model).

\section{Marketing channels}

Marketing channel differs according to the location of the villages. The villages located nearby Aizawl city directly disposed their produce to the consumers in the city market without the interference of the middlemen which was seen in Tachhip village. In Sialsuk village, majority of the produce were disposed to nearby hotels. In East Phaileng village, village traders played an important role since the distance between the city market and the village is more, the farmers could not dispose their produce directly to the buyers. The village traders procured from the producers and acted as a retailer and disposed to the consumers in the city market.

Two marketing channels seen in the study area are:

\section{Channel I}

Producer $\rightarrow$ Consumer

\section{Channel II}

Producer $\rightarrow$ Village trader $\rightarrow$ Consumer

\section{Channel-wise price spread and marketing margin}

As indicated by the price spread analysis in Table 4, the producer received Rs. 16377.8 and the price paid by the consumer was Rs. 17000. The farmer obtained 96.34 per cent of price paid by consumer in marketing Channel I. In case of channel 2 (Table 5), the price received by producer and village trader were
Rs. 9880 and Rs. 13562 respectively and the price paid by the consumer was Rs. 24000 . The producer received only $41.20 \%$ of consumer's rupee and the village trader received $56.50 \%$ of the consumer's rupee. In Channel I, the total marketing cost borne by producer was Rs. 697.2 (4.10\% of consumer's rupee) and in case of marketing channel II it was found to be Rs. $110 \quad(0.45 \%$ of consumer's rupee). The total marketing cost borne by village trader in channel II was Rs. 438 (1.82\% of consumer's rupee). It is seen from Table 4 and 5, the producer's share in consumer rupee was higher in channel I compared to channel II because of the absence of middlemen.

\section{Marketing efficiency}

Marketing efficiency index ratio according to Acharya-Agarwal method was found to be 23.49 in Channel I and 0.70 in Channel II. There was a wide variation between the presence and absence of middlemen. The net price received by producers was considerably lower than the margin obtained by the middlemen which shows that the farmers were highly exploited by the middlemen. The main reason is inadequate means of transport in East Phaileng village which hindered the farmers to practice direct sale in city market. Other reasons include lack of information regarding prices prevailing in the market, lack of farmers' organization etc. (Table 6).

In conclusion the study showed that the output obtained per hectare is low although the net income is nominal due to high price of chilli in the market. Farmers should be made aware of the appropriate dosage of fertilizers and plant protection chemicals. The findings also showed that village traders highly exploited the farmers which were attributed to lack of transportation, market information and farmers' organization. The government should take measures to improve the mode of 
transportation by making availability of public transports in East Phaileng village which will help the farmers to dispose their produce directly in the city market. The farmers should also be encouraged to form Farmers' cooperative societies so that they can dispose their produce in bulk and increase their bargaining power. The Government should also strengthen the market information system to safeguard the farmers from manipulation of prices by the traders.

\section{References}

Banchhor, S.K and Kumar, D. 2017.An economic analysis of production and marketing of chilli in Durg district of Chhattisgarh. Journal of
Pharmacognosy and Phytochemistry. 6 (5): 1291-1293.

Jagtap, P.P., Shingane, U.S and Kulkarni, K.P. 2014. Resource use efficiency and economics of marketing of green chilli. Journal of Spices and Aromatic Crops. 23 (1): 32-37.

Rajur, B.C and Patil, B.L. 2015. Price spread, marketing costs and margins of chilli in Karnataka state. Karnataka Journal of Agriculture Sciences. 23 (3): 364368.

Sashimatsung and Giribabu. 2015. Economic analysis on production and marketing of Chilli in Mokokchung District of Nagaland. Journal of Marketing and Consumer Research. 13: 21-36.

\section{How to cite this article:}

Lalhminghlui, G. Sunil Kumar Babu, R. Asha, S. Shrine and Gousiya, Sk. 2020. An Economic Analysis of Production and Marketing of Mizo Bird's Eye Chilli (Mizo Chilli) in Aizawl District of Mizoram State. Int.J.Curr.Microbiol.App.Sci. 9(10): 1448-1454. doi: https://doi.org/10.20546/ijcmas.2020.910.172 